\title{
Effect of Ocimum Sanctum Linn (Tulsi) on body weight and some biochemical parameters in restraint stressed albino rats
}

\author{
Siraji D ${ }^{1}$, Islam N², Begum N ${ }^{3}$, Ferdousi $\mathrm{S}^{4}$
}

Background: With the increased trend of urbanization of our society, the incidence of various stress related diseases are increasing day by day. People under chronic stress often tends to seek relief through drugs, which may have side effects. But some natural supplements called adaptogen, can be more beneficial in reducing symptoms of stress. Objective: The present animal model experimental study was designed to observe the effects of restraint stress on body weight, serum ALT, AST, Glucose, Cholesterol and their modifications by Ocimum sanctum Linn (tulsi) pretreatment which is an Ayurvedic adaptogen and has a long history of therapeutic use. Study design: For this purpose, 30 albino rats aged 90 to 120 days were included in this study. Twenty rats of experimental group were further subdivided into two groups. One group consisted of 10 rats exposed to one hour restraint stress daily for 7 days and 10 rats of the second group were pretreated with tulsi for 7 days before exposure to stress in the same way. 10 non stressed, non pretreated rats were taken into control group.This study was undertaken in the laboratory of the Department of Physiology,BSMMU during the period from July 2003 to June 2004. Methods: The body weight of all control rats were recorded daily in the morning. Body weight of the experimental rats were recorded just before exposure to stress. After completing the experiment, the animals were sacrificed and blood was collected . Serum glucose, cholesterol and ALT,ASTwere determined by standard laboratory technique. Data were compared among the groups and the results were statistically analyzed using unpaired student $t$ ' test. Results : The body weight in untreated stressed group was significantly lower $(\mathrm{p}<0.001)$ than those of the control group and tulsi pretreated group. Serum levels of glucose, cholesterol, aminotrasferases (ALT and AST) were significantly higher $(\mathrm{p}<0.001)$ in stressed group than those of control . Again in Tulsi treated group all these biochemical parameters were significantly lower $(p<0.001)$ than those of stressed group. This restraint stress-induced changes in body weight and biochemical parameters may be due to hypophagia, altered secretion of various metabolic hormones and neurotransmitters, changes in membrane permeability \& hypovolaemia resulting from stress induced secretion of corticosterone and epinephrine through hypothalamo-pituitary adrenal axis activation. Conclusion: Prevention of stress induced changes in biochemical parameter by tulsi pre treatment indicates its anti stressor effect.

Key words: Restraint stress; adaptogen;Ocimum sanctum Linn (tulsi); glucose; cholesterol; ALT; AST.

J Bangladesh Soc Physiol.2008 Dec;(3):29-34. For author affiliations, see end of text.

http://www.banglajol.info/index.php/JBSP

Introduction:

tress is a condition of highly individualized
response of an organism to external or
internal challenges which one can control with difficulties or cannot control. Most of the scientists define, stress as the situation when activation of hypothalamo-pituitary adrenocortical (HPA) axis occurs with consequent elevated adrenocorticotropic hormone level ${ }^{1}$. Other investigators suggest the involvement of activation of different

J Bangladesh Soc Physiol. 2008 Dec;(3):29-34 
systems, such as autonomic nervous system with or without elevation of ACTH ${ }^{2,3}$.

Stressor may be external or internal. External stressors include adverse physical environment such as exposure to excessive light, sound, immobilization etc. and stressful psychological environment like poor working condition or abusing relationship. Similarly internal stressors can also be physical like infection, inflammation or psychological such as anxiety, fear and frustration.

It has been accepted that central nervous system plays an important role on elicitation and modulation of compensatory stress response pattern. A variety of neurotransmitters and neuromodulators are released in various brain regions during exposure to stress, which then act on specific neuronal circuits to optimize an effective, rapid and efficient responses to restore disturbed homeostasis and ensure minimal damage to other organs ${ }^{4}$. Acute stress responses are usually of short lasting and less marked. In chronic stressful situations, responses are prolonged, and hyper active due to repeated stimulation. Elevated hormone levels for prolonged period can become dangerous for an organism manifested by significant changes in behavior, functional ability, body weight, biochemical and immunological systems. So, overstimulated stress response can cause damage to the various organs ${ }^{5 .}$

Seelye et al. was the first researcher who used immobilization stress (restraint stress)in rats to explore the manifestation of stress syndrome i.e., adrenal hypertrophy, gastric ulceration and thymicolymphatic involution ${ }^{6}$. In stress management, relaxation and biofeedback can help to treat chronic stress hazards especially in combination with medicine ${ }^{7}$. But all these may lead to side effects to the patient. Now a days, a range of natural supplement such as herbal medicine, known as adoptogens which are devoid of side effects , can be more beneficial in reducing stressinduced symptoms ${ }^{7}$. Adaptogen is an agent that allows the organism to encounter adverse physical, chemical or biological stressors by raising nonspecific resistance towards such stress though the mode of action is not fully understood, but considerable amount of evidence suggest that its effects are mediated by the pituitary and hypothalamo- pituitary adrenal (HPA) axis ${ }^{8}$. In addition, Adaptogens are also having antioxidant, anti-cancer, immunomodulator, hypocholesterolaemic and hypoglycemic effects ${ }^{9}$. One of the ayurvedic adoptogen is Ocimum sanctum Linn known as holy basil in English, as tulsi in Hindi. It has a long history of medicinal use in pain, fever, vomiting, bronchitis, earache and disease of heart and blood ${ }^{10}$. To combat restraint stress induced changes and their prevention by treatment with adaptogen especially by O. sanctum Linn ( tulsi ) are not well documented. It has been speculated that restraint stress induced changes are noticeable in body physiology which is reflected by changes in body weight and some biochemical parameters .Again, such changes can be reversed or prevented with an adaptogen such as tulsi. So, this study was designed to observe the effects of tulsi on some biochemical parameters like serum glucose, cholesterol, alanine aminotranfease (ALT) and aspartate aminotransferase (AST) as well as on body weight of a group of rats exposed to restraint stress.

\section{Methods:}

This is a prospective experimental study carried out in the department of Physiology, BSMMU Dhaka during the period from July 2003 to June2004. For the purpose of study, 30 male long Evans strain Albino rats of 90 to 120 days old, weighing 150 to $200 \mathrm{~g}$ were included and collected from animal house of pharmacology department , BSMMU. The rats were housed properly in numbered iron cages in a clean animal house with an optimal room temperature (25 to $30^{\circ} \mathrm{C}$ ) and were kept on basal laboratory diet and water ad libitum for one week before commencing the experiment for acclimatization.

Rats were divided into three groups according to the state of exposure to stress. Each group consisted of 10 rats. Non stressed control group (Group A) were not put on restrain stress. Stress group (Group B) were exposed to restrain stress and tulsi pretreated group (Group C) was treated

J Bangladesh Soc Physiol. 2008 Dec;(3):29-34 


\section{Article}

Effect of Tulsi on Stressed rats

Table-II

Mean ( \pm SE) of Serum Glucose and Cholesterol levels in different study groups $(n=30)$

\begin{tabular}{lccc}
\hline Group & $\mathrm{n}$ & Glucose $(\mathrm{mmol} / \mathrm{L})$ & Cholesterol(mg/dl) \\
\hline A & 10 & $5.9 \pm 0.3$ & $72.3 \pm 6.8$ \\
B & 10 & $7.8 \pm 0.2$ & $104.3 \pm 2.6$ \\
C & 10 & $5.6 \pm 0.2$ & $61 \pm 5.3$ \\
\hline Statistical analysis & & P value \\
\hline Groups & & $<.001$ & $<.001$ \\
Avs B & $<.001$ & $<.001$ \\
BvsC & 0.50 & 0.50 \\
CvsA & & &
\end{tabular}

Group A : Control ( non stressed, non treated).

Group B : Experimental ( exposed to restraint stress)

Group C : Experimental ( tulsi pretreated and exposed to restraint stress)

Table -III

Mean ( $\pm S E)$ of Serum ALT and AST levels in different study groups $(n=30)$

\begin{tabular}{lccc}
\hline Group & $\mathrm{n}$ & ALT(IU/l) & AST (IU/l)) \\
\hline A & 10 & $49.6 \pm 2.8$ & $141.3 \pm 6.1$ \\
B & 10 & $77 \pm 3.4$ & $164.2 \pm 7.3$ \\
C & 10 & $46.1 \pm 1.4$ & $138.41 \pm 4.8$ \\
\hline Statistical analysis & & P value & $<$ value \\
\hline Groups & & $<.001$ & $<.001$ \\
Avs B & $<.001$ & $<.001$ \\
BvsC & 0.10 & 0.10 \\
CvsA & & &
\end{tabular}

Group A : Control ( non stressed, non treated).

Group B : Experimental ( exposed to restraint stress)

Group C : Experimental ( tulsi pretreated and exposed to restraint stress)

\section{Discussion :}

This study was undertaken to observe the effects of restraint stress on some biochemical parameters, and their modifications by tulsi pretreatment in albino rats. The results of body weight changes are similar to those of other researchers ${ }^{12}$, but it was lowered than that of Harris et $\mathrm{al}^{13}$. It is well established that corticotrophin - releasing hormone influences feeding behavior and mediate in behavioral and physiological response to stress ${ }^{14}$ Several investigators have mentioned, $\mathrm{CRH}$ induced anorexia during stress. This may be due to either activation of serotonin pathways or inhibition of neuropeptide Y release. ${ }^{15}$ - 16 .Neuropeptide Y is a potent stimulator of food intake ${ }^{17}$. It has been suggested that restraint stress induces suppression of weight gain occur due to depression and anorexia ${ }^{16}$.

J Bangladesh Soc Physiol. 2008 Dec;(3):29-34 
Serum glucose level in this study was found higher in stress group than those of Tulsi pretreated group which is similar to those of control group. Several studies shown that Tulsi has a hypoglycemic action ${ }^{18-20}$.

Cholesterol level was significantly higher in stress group which is similar to those reported by others ${ }^{21}$. It has been suggested that various forms of stress raised the cholesterol level by disturbing rate of synthesis and excretion ${ }^{22}$. Various authors have suggested that this change is due to the effect of epinephrine on lipoprotein lipase, hormone sensitive lipase and hepatic lipase ${ }^{23,24}$. Patterson et al. suggested that psychological stress caused decreased volume, producing hemaconcentration which might be a secondary cause of increased cholesterol level ${ }^{25}$.

Stress induced cholesterol level was also lowered in Tulsi pretreated group which is similar to the results reported by some other groups of investigators ${ }^{26,27,18}$.

ALT and AST were significantly higher in stress group .Similar observations were also made by some investigators ${ }^{28-30}$. Tulsi has significantly controlled the stress induced alteration of serum ALT and AST level. Stress causes alteration in the membrane permeability of the cells or injury to the cells due to release of intracellular enzymes into the systemic circulation. ${ }^{18,} 23$. Autonomic nervous system plays a great role in this change by modulation of cell structure as well as cell permeability resulting in excessive Ca influx which in turn damages the cytoskeleton and cause leakage of intracellular enzyme to the outside ${ }^{31}$. Although there is no such available data to compare the effect of tulsi on restrained stress induced changes in relation to serum levels of ALT and AST but it was reported that elevation of corticosterone was prevented by tulsi ${ }^{32}$. They also suggested that such prevention may be due to the blockade in release of ACTH through HPA axis. So tulsi extract may have a central action.

J Bangladesh Soc Physiol. 2008 Dec;(3):29-34

\section{Conclusion:}

From the result of this study it can be concluded that stress may cause reduction in blood glucose, cholesterol ALT and AST status and body weight as well which can be prevented by pretreatment with tulsi extract.

Although this study may confirm the anti stress effect of tulsi but the mechanism of this adaptogen was not studied. But before recommending the extract of tulsi as a therapeutically active agent against stress, further study should be done in this field.

\section{Author Affiliations}

*1. Dilruba siraji,Associate Professor ,Department of Physiology, Chattaragam Maa-O-Shishu Hospital Medical College, Agrabad,Chittagong. Email:anjum_mow@yahoo.com

2. Nadira Islam, Professor, Department of Physiology, BSMMU Email:nadira03islam@yahoo.ca

3. Noorzahan Begum ,Professor and Chairman, Department of Physiology, BSMMU, E mail: Noorzahanbeg@yahoo.com

4. Sultana Ferdousi, Assistant Preofessor, Department of Physiology,BSMMU, E mail:sferdousiratna@yahoo. com

\section{* For correspondence}

\section{References:}

1. Ganong WV,Review of medical physiology Norwalk: Appleton and Lange, 1995, p327-351.

2 Vigas M,. Neuroenokrinna reakci v strese u cloveka. In: Veda (ed) Bratislava . 1985.

3 Pacak K, Palkovits M, Yadid G, Kvetnansky R, Kopin IJ , Goldstein DS. Heterogenous neurochemical responses to different stressors: a test of Seley's doctrine of nonspecificity. Am J Physiol 1998; 275: R1247 - 1255 .

4 Gaillet S, Lachuer j, Malaval F, Assnmacher I, Szafarczyk A, The involvement of non adrenergic ascending pathways in the stress induced activation of ACTH and corticosterone secretion is dependent on the nature of stressors. Exp Brain Res 1991;87:173-180.

5 Mc Ewen BS. Stress brain and behavior: life long effects upon health and disease. In : Kinney JM, Tucker HN (ed). Physiology, stress and malnutrition. Functional correlates of nutritional intervention. Philadelphia: Lippincott-Raven 1997.P113-130. 
6 Selye $\mathrm{H}$. Thymus and adrenals in the presence of the organism to injuries and intoxications. Br J Exp Pathol 1936; 17: 234-248.

7 Holroyd KA, O’Donnell FJ, Stensland M, Lipchik GL, Cordingley GE, Carlson BW. Management of chronic tension -type headache with tricylic anti depressant medication, stress management therapy and their combination. J A m Med Assoc 2001; 285 (17) :22082215.

8 Wagner $\mathrm{H}, \mathrm{N}$ orr $\mathrm{H}$,Wainterhoff $\mathrm{H}$. Plantadaptogen . Phytomedicine 1994;1:63-76.

9 Dardymov M, Krikorian AD. Eleutherococcus senticosus( Rupr and Maxim ) Maxim (Araliaceae ) as an adaptogen: a closer look, J Ethnopharmacol 2000;72: 345-393.

10. Maity TK, Mandal SC, Saha BP, Pal M. Effect of Ocimum sanctum roots extract on swimming performance in mice. Phytotherapy Res 2000; 14:120121.

11. Bhargava KP, Singh N. Anti stress activity of ocimum sanctum linn . Indian J Med Res 1981; 73:443-451.

12. Nagaraja HS, Jeganathan PS. Effect of short and long term restraint stress on some physiological and biochemical parameters in rats. Indian J Med Res 1999;

13. Harris RBS, Zhou J, Youngblood BD, Rybkin II,Smagin GN, Ryan DH. Effect of repeated stress on body weight and body composition of rats fed low and high fat diets. Am J Phyiol Regul Integr Comp Physiol 1998;275; R1928-1938.

14 . Sutton RE, Koob GF, Le Moal M, Rivier J, Vale W. Corticotropin releasing factor produces behavioral activation in rats. Nature 1982; 297: 331-333.

15. Kennet GA, Chaouloff F, Marcou M, Curzon G. Female rats are more vulnerable than males in an animal model of depression : the possible role of serotonin. Brain Res 1986;382:416-421.

16. Shimizu N, Oomura Y, Kai Y. Stress induced anorexia in rats mediated by serotonergic mechanisms in the hypothalamus. Physiolo Behav 1989; 46: 835-841.

17. Heinricks SC, Menzaghi F, Pich EM, Hauger RL, Koob GF, Corticotropin - releasing factor in the paraventricular nucleus modulates feeding induced by neuropeptide Y. Brain Res 1993;611:18-24.

18. Agrawal P, Rai V, Singh RB. Randomized placebocontrolled, single blind trial of holy basil leaves in patients with non insulin dependent diabetes mellitus. Int J Clin Pharmacol Therapeut.1996;34: 406-409.

19. Chattopadhyay RR. Hypoglycaemic effect of Ocimum sanctum leaf extract in normal and streptozotocin diabetic rats. Indian Exp Biol 1993;31: 891-893.

20. Rai V, Iyer U, Mani UV, Effect of tulsi leaf powder supplementation on blood sugar levels, serumlipids and tissue lipids in diabetic rats. Plant Foods Human Nutr. 1997; 50: 9-16.

21. Jain SK, Pandey SN, Srivasta RK, Ghosh SK. Stress and serum cholesterol an experimental study. J Anatom Soc India 2000;49:165-167.

22. Champe PC, Harvey RA, Enzyme . In : Lippincott's illustrated reviewes : biochemistry, 2 nd ed . Philadelphia : Lippincott-Raven Publishers, 1994a . P47-60.

23. Lunderberg U, Fredrikson M, Wallin L, Melin B,Frankenhaeuser M. Blood lipids as related to cardiovascular and neuroendocrine functions under different conditions in healthy males and females. Pharmacol Biochem Behav 1989;33:381-6.

24. Muldoon MF, Herbert TB, Patterson SM, Kameneva M, Raible R , Manuck SB . Effects of acute psychological stress on serum lipid levels, hemaconcentration and blood viscosity. Arch Intern Med 1995; 155: 615-620.

25. orcelli P, Leandro G, De Carne M . Functional gastrointestinal disorders and eating disorders. Relevence of the associations in clinical management . Scand J Gastroenterol 1998 ; 33 : 577-582.

26. Sen P, Maiti PC. Puri S, RayA, Audulov NA, Valdman AV. Mec10hanism of anti stress activity of Oci9mum sanctum Linn, eugenol and Tinospora malabaica in experimental animals. Indian J Exp Biol 1992; 30(7): 592-596.9:76-80.

27. Sarkar A ,Lavania SC, Pandey DN, Pant MC. Changesin the blood lipid profile after administration of Ocimum Sanctum ( tulsi) leaves in the normal albino rabbits . Indian J Physiol Pharmacol 1994; 38 (4) ; 311-312.

28. Lalitha R, Suthanththirajan N, Namasivayam A. Effect of flickering light stress on certain biochemical parameters in rats. Indian J Phsiol Pharmacol 1988;32: 182-186.

29. Haque JA. Study of stress induced alteration of some biochemical parameters on rats. [ M Phil thesis]. Dhaka ; Department of Physiology, Institute of Post graduate Medicine and Research 1991.

30. Arakawa H, Kodama H, MatsuokaN, Yamaguchi I . Stress increases plasma enzyme activity in rats: differential effects of adrenergic and cholinergic blockades. J Pharmacol Exper Therap 1997; 280: 1296-1303.

31. Ahlersova E, Ahler I. The effect of adrenergic blocking agents and nicotinic acid on lipid and carbohydrate metabolism in immobilized rat .In: Usdin E, Kvetnansky R, Kopin U (ed) . Catecholamines and stress. Oxford: Pergamon Press,1976 .P491-497.

32. Sembulingam K, Sembulingam I,Namasivyam A. Effect of Ocimum sanctum Linn on noise induced changes in plasma crticosterone level. Indian J Physiolo Pharmacol 1997;41: 139-143.

J Bangladesh Soc Physiol. 2008 Dec;(3):29-34 